\title{
Analisa Fasilitas Safety Building Sebagai Upaya Pencegahan Kebakaran Di Gedung Fakultas Ilmu Keolahragaan Universitas Negeri Malang
}

\author{
Lingga Fitriana Sarida, Moch. Yunus*, Sendhi Tristanti Puspitasari \\ Universitas Negeri Malang, Jl. Semarang No. 5 Malang, Jawa Timur, Indonesia \\ *Penulis korespondensi, Surel: moch.yunus.fik@um.ac.id
}

Paper received: 1-10-2021; revised: 19-10-2021; accepted: 25-10-2021

\begin{abstract}
A fire hazard is one of the potential hazards of Occupational Safety and Health or K3 in buildings. In high-rise buildings, escape routes are few and limited, necessitating the implementation of effective, efficient, and integrated fire prevention measures. The purpose of this study is to determine the completeness of safety building facilities, to identify and analyze the feasibility of safety building facility function, and to design efforts to optimize the functional safety building facilities in the C6 FIK UM building. This descriptive qualitative research was conducted in the C6 FIK UM building using the method of observation and document review. Building fire safety inspection observation guidelines (Pd-T-11-2005-C) are used to measure the reliability value of building safety systems (NKSKB), and John Stephenson Associates Fire Training Consultants observation guidelines are used to measure the level of risk and priority of action. The findings of the research and assessment of the NKSKB of the FIK UM building received a score of 89.76 percent and were classified as good. The FIK UM building has a low to moderate risk level, and the priority actions that must be taken are engineering and administrative arrangements. The FIK UM building falls into the good category and can be considered reliable in fire prevention efforts; however, it must be tested, inspected, recorded, and repaired regularly.
\end{abstract}

Keywords: fire hazard; buildings; building reliability

\begin{abstract}
Abstrak
Potensi risiko bahaya Keselamatan dan Kesehatan Kerja atau K3 pada bangunan gedung salah satunya adalah bahaya kebakaran. Akses menyelamatkan diri pada bangunan gedung bertingkat adalah sedikit dan terbatas, sehingga diperlukan tindakan pencegahan kebakaran yang efektif, efisien, dan terintegritas. Penelitian ini bertujuan untuk mengidentifikasi kelengkapan fasilitas safety building, mengidentifikasi dan menganalisis kelayakan fungsi fasilitas safety building, dan merancang upaya optimalisasi fungsional fasilitas safety building pada gedung C6 FIK UM. Jenis penelitian ini yaitu deskriptif kualitatif yang dilakukan di gedung C6 FIK UM dengan metode observasi dan telaah dokumen. Instrumen yang digunakan yaitu pedoman observasi pemeriksaan keselamatan kebakaran bangunan gedung (Pd-T-11-2005-C) dengan mengukur nilai keandalan sistem keselamatan bangunan (NKSKB) dan pedoman observasi John Stephenson Associates Fire Training Consultants dengan mengukur tingkat risiko dan prioritas tindakan. Hasil penelitian dan penilaian NKSKB bangunan gedung FIK UM memperoleh nilai $89,76 \%$ dan termasuk dalam kategori baik. Tingkat risiko pada gedung FIK UM yaitu risiko rendah hingga resiko sedang dan prioritas tindakan yang perlu diambil adalah rekayasa teknik dan pengaturan administratif. Gedung FIK UM termasuk dalam kategori baik dan dapat dikatakan handal dalam upaya pencegahan kebakaran, tetapi perlu dilakukan pengujian, pemeriksaan, pencatatan, dan perbaikan secara berkala.
\end{abstract}

Kata kunci: bahaya kebakaran; gedung; keandalan bangunan

\section{Pendahuluan}

Wujud fisik dari pekerja konstruksi yang berada di atas atau di dalam tanah atau air, yang berfungsi sebagai kepentingan publik dan sudah ditetapkan sesuai dengan pemenuhan 
persyaratan teknis merupakan definisi dari bangunan gedung (Wulandari \& Trikomara, 2018). Bangunan gedung yang relatif aman dihadapkan dengan berbagai risiko bahaya keadaan darurat dan keselamatan menjadi syarat penting suatu bangunan gedung (Gultom et al., 2018). Klasifikasi bangunan gedung dapat dilihat dari fungsi penggunaan bangunan gedung berdasarkan pemenuhan tingkat persyaratan administratif, persyaratan teknis, dan fungsi yang digunakan dalam perencanaan pelaksanaan, atau perubahan yang diperlukan pada bangunan gedung (Reinaldo, 2018). Kelengkapan sarana dan prasarana pemanfaatan bangunan gedung dan lingkungan harus sesuai dengan kebutuhan seluruh kelompok usia dan kondisi keterbatasan fisik, mental dan intelektual atau sensorik guna mempermudah pengguna atau pengunjung dalam beraktivitas di dalam bangunan gedung (Riskiyanto et al., 2018).

Kebakaran merupakan suatu bencana atau musibah yang terjadi karena adanya tiga faktor yang menjadi unsur api, dapat terjadi kapan saja dan dimana saja, serta dapat menimbulkan kerugian harta benda hingga kematian (Mustika et al., 2018). Kerugian dapat timbul dikarenakan adanya ketimpangan pada alat seperti tidak berfungsinya deteksi dan alarm, tidak tersedia deteksi dan alarm, APAR yang kurang memadai atau tidak tersedia, dan lainnya (Setyawati \& Suhardi, 2018). Kebakaran diklasifikasikan berdasarkan sumber api dengan kelas A, B, C untuk mempermudah upaya pencegahan dan pemadaman kebakaran (Hambyah, 2016). Tahapan proses pengembangan api kompartemen ada empat yaitu tahap awal kebakaran, tahap pertumbuhan api, tahap perkembangan api penuh dan tahap resesi kebakaran (Chen et al., 2019). Pencegahan kebakaran merupakan antisipasi dan usaha preventif agar tidak terjadi kebakaran atau meminimalisir risiko terjadinya kebakaran, serta penanggulangan kebakaran merupakan upaya dan tindakan penyelamatan pada saat terjadinya kebakaran secara efektif dan efisien (Harianja et al., 2020).

Kebakaran terjadi di salah satu pusat perguruan tinggi India yang menyebabkan 19 siswa meninggal dan banyak yang melompat dari gedung untuk menyelamatkan diri (Michico, 2019). Kebakaran juga terjadi di salah satu laboratorium Undiksha Singaraja yang disebabkan oleh korsleting listrik dan diperlukan tiga armada pemadam kebakaran untuk memadamkan api (Raharjo, 2020). Laboratorium teknik hasil hutan di Universitas Palangka Raya (UPR) mengalami kebakaran yang diakibatkan oleh korsleting listrik yang berada di atap gedung dan mengakibatkan kerugian materiil mencapai Rp. 250.000.000,00 (Dodi, 2020). Kuartal pertama tahun 2020 yaitu antara 01 Januari 2020 - 09 April 2020, Indonesia mengalami kejadian kebakaran sebanyak 161 kejadian dengan korban meninggal dan hilang berjumlah 5 orang, luka-luka berjumlah 2 orang, mengungsi dan terdampak 417 orang dengan kerugian materiil sebanyak 247 rumah rusak berat, 3 rumah rusak sedang, 21 rumah rusak ringan dan 4 fasilitas pendidikan rusak (Data Informasi Bencana Indonesia, 2020). Kebakaran di Kota Malang dengan kasus yang cukup besar terjadi di trafo listrik RS Syaiful Anwar dengan kerugian materiil mencapai lebih dari 6 miliar pada bulan februari tahun 2019 (BPBD, 2020). Penelitian yang dilakukan di PT PJB UP Brantas Malang menyatakan bahwa perlu upaya pencegahan dan penanggulangan terkait kebakaran pada setiap tempat untuk menghindari terjadinya kebakaran yang dapat menimbulkan kerugian dalam jumlah besar (Kowara \& Martiana, 2017).

Penyebab kebakaran dapat beragam, namun bisa dikategorikan dalam dua aspek yaitu kecerobohan manusia, gagalnya sistem "engineering" bangunan, dampak penggunaan energi seperti listrik, bahan bakar, tabung oksigen dan bahan kimia (Kowara \& Martiana, 2017). Di Indonesia kegagalan sistem lebih tinggi, khususnya kegagalan sistem kelistrikan dalam 
bangunan misalnya hubungan arus pendek listrik (Sufianto et al., 2015). Bangunan gedung memiliki risiko potensi bahaya Keselamatan dan Kesehatan Kerja (K3), gedung Fakultas Ilmu Keolahragaan Universitas Negeri Malang merupakan salah satu bangunan gedung yang memiliki fungsi sosial dan budaya karena terdapat manusia yang melakukan kegiatan sosial dan budaya seperti kegiatan perkuliahan dan bekerja. Bangunan gedung Fakultas Ilmu Keolahragaan Universitas Negeri Malang atau yang bisa disingkat dengan FIK UM memiliki delapan lantai dan telah diresmikan tanggal 7 Januari 2020, yang dapat dikatakan bahwa gedung FIK UM merupakan bangunan gedung yang baru beroperasional. Hasil observasi pendahuluan yang dilaksanakan oleh peneliti menunjukkan bahwa setiap lantai memiliki APAR yang diletakkan secara terpisah dan dapat dijangkau oleh penghuni dan pengguna gedung. Setiap lantai memiliki dua hydrant yang berada di ujung lorong. Setiap lantai memiliki dua jalur evakuasi yang terletak di sisi timur dan barat gedung, memiliki dua pintu darurat dan dua tangga darurat yang digunakan sebagai jalur evakuasi. Kondisi pintu darurat mudah dibuka dan kondisi tangga darurat juga tidak terhalang apapun, tetapi kondisi pintu yang berat dan tangga darurat yang tidak dibersihkan dapat menimbulkan masalah kesehatan yang lain, di sebelah tangga darurat juga terdapat lift. Setiap lantai juga memiliki sprinkler dan heat detector baik di dalam ruang perkuliahan maupun di luar ruang perkuliahan. Media pemberitahuan bila terjadi bencana baik audio maupun visual, tidak dimiliki oleh gedung FIK UM.

Hasil wawancara singkat yang dilaksanakan oleh peneliti pada tanggal 30 Maret 2020 dengan Kepala Sub Bagian Umum dan Keuangan FIK UM, memberikan informasi bahwa gedung FIK UM memiliki koridor, selasar gedung yang terletak di depan gedung, tangga darurat, pintu darurat, penunjuk arah pintu keluar, tetapi tidak memiliki pencahayaan darurat, titik kumpul, peta evakuasi, dan penangkal petir. Gedung FIK UM wajib memiliki fasilitas safety building yang baik dan juga lengkap baik di sistem proteksi kebakaran maupun sarana penyelamatan jiwa, karena gedung tersebut merupakan gedung delapan lantai yang setiap hari digunakan oleh banyak orang karena terdapat ruang gym, ruang perpustakaan, ruang administrasi, ruang seminar, ruang perkuliahan, ruang laboratorium, dan aula. Hasil observasi dan wawancara pendahuluan yang telah dilakukan oleh peneliti, gedung FIK UM belum optimal dalam memenuhi fasilitas safety building sehingga dapat menimbulkan hal yang tidak diinginkan dan dapat membahayakan semua pihak.

Atas dasar data dan kondisi diatas, penelitian ini dilakukan untuk mengidentifikasi fasilitas safety building yang ada di Gedung Fakultas Ilmu Keolahragaan Universitas Negeri Malang atau yang dapat disingkat FIK UM untuk upaya pencegahan dan penanggulangan bahaya yang mungkin dapat terjadi kapan saja berdasarkan standar keselamatan yang ada. Adapun keterbaruan dari penelitian ini adalah peneliti merekomendasikan adanya perbaikan dan melengkapi tentang fasilitas keselamatan bangunan gedung.

\section{Metode}

Penelitian ini merupakan penelitian deskriptif kualitatif dengan mengamati sarana dan prasarana safety building yang ada pada bangunan gedung FIK UM. Pendekatan deskriptif pada penelitian ini bertujuan untuk mengetahui dan menyajikan fakta pada saat dilakukan penelitian (Lestari \& Winarno, 2020). Penelitian deskriptif kualitatif ini hanya sebatas penilaian terhadap fasilitas safety building di Gedung FIK UM dengan dua pedoman observasi, agar lebih mudah dipahami dan disimpulkan (Dipiarsa et al., 2020). Data pada penelitian ini diperoleh dari telaah dokumen, observasi dan dokumentasi. Instrumen yang digunakan adalah 
lembar pedoman observasi dari Badan Litbang PU Departemen Pekerjaan Umum Pd-T-112005-C dan penilaian dilakukan dengan cara menilai tingkat keandalan terhadap sub komponen dengan parameter penilaian yang terdapat pada tabel 1, serta pedoman observasi John Stephenson Associates Fire Safety/Training Consultants yang menilai tingkat risiko berdasarkan matriks risiko untuk menentukan level risiko yang ada di tempat penelitian dengan parameter penilaian yang terdapat pada tabel 2. Peneliti telah melaksanakan uji etik yang bertempat di Poltekkes Kemenkes Malang dengan nomor sertifikat Reg.No.:037 / KEPKPOLKESMA/ 2021. Penelitian dilakukan di bangunan gedung Fakultas Ilmu Keolahragaan Universitas Negeri Malang.

Tabel 1. Tingkat Penilaian Audit Kebakaran

\begin{tabular}{clc}
\hline Nilai & \multicolumn{1}{c}{ Kesesuaian } & Keandalan \\
\hline$>80-100$ & Sesuai persyaratan & Baik (B) \\
$60-80$ & Terpasang tapi ada sebagian kecil instalasi yang tidak sesuai & Cukup (C) \\
& persyaratan & \\
$<60$ & Tidak sesuai sama sekali & Kurang (K) \\
\hline
\end{tabular}

Tabel 2. Penilaian Tingkat Risiko dan Prioritas Tindakan

\begin{tabular}{ll}
\hline \multicolumn{1}{c}{ Tingkat Risiko } & \multicolumn{1}{c}{ Prioritas Tindakan } \\
\hline Risiko Sangat Tinggi & Tindakan harus diselesaikan segera (Wajib Sangat) \\
Risiko Tinggi & Tindakan harus diselesaikan dalam waktu tiga bulan (Wajib) \\
Risiko Sedang & Tindakan harus diselesaikan dalam waktu enam bulan (Sangat \\
Risiko Rendah & Direkomendasikan) \\
\hline
\end{tabular}

\section{Hasil dan Pembahasan}

\subsection{Kelengkapan Fasilitas Keselamatan Bangunan Gedung FIK UM dari Bahaya Kebakaran}

Bangunan gedung FIK UM memiliki fasilitas safety building yang dapat menunjang keandalan bangunan gedung. Fasilitas safety building yang tersedia pada bangunan gedung FIK UM hampir memenuhi persyaratan kelengkapan fasilitas dalam upaya pencegahan kebakaran. Hasil NKSKB yang diperoleh bangunan gedung FIK UM yaitu sebesar 89,76\% dan termasuk kategori baik. Fasilitas kelengkapan tapak yang tersedia di bangunan gedung FIK UM termasuk kategori baik, meskipun terdapat salah satu sub komponen yang masuk kedalam kategori kurang. Fasilitas sarana penyelamatan jiwa yang tersedia di bangunan gedung FIK UM termasuk kategori baik.

\subsection{Kelengkapan Tapak}

Kelengkapan tapak pada bangunan gedung FIK UM termasuk kategori "B" (Baik) dengan jumlah nilai $21,87 \%$ dari $25 \%$. Pemenuhan kriteria penilaian yang terdapat pada Pd-T-112005-C memiliki manfaat bagi bangunan gedung FIK UM, yaitu dapat mengetahui sub komponen apa saja yang tidak memenuhi kriteria penilaian. Sub komponen sumber air, jalan lingkungan dan jarak antar bangunan termasuk kategori "B" (Baik), sedangkan sub komponen hidran halaman termasuk kategori "K" (Kurang). Sub komponen sumber air pada bangunan 
gedung FIK UM telah mendapat kategori "B" (Baik) dengan nilai sebesar 6,75\% dan dapat menjadi sebuah keuntungan karena pemenuhan kriteria pada sub komponen sumber air telah sesuai dengan persyaratan. Ground reservoir pada bangunan gedung FIK UM memiliki volume sebesar $60 \mathrm{~m}^{3}$ dan memiliki 2 roof tank yang masing-masing memiliki volume sebesar $8 \mathrm{~m}^{3}$. Sub komponen jalan lingkungan pada bangunan gedung FIK UM telah memenuhi persyaratan yang berlaku dengan nilai 5,62\% dan termasuk kategori baik. Jalan lingkungan juga memiliki bagian penting dalam upaya perlindungan terhadap bahaya kebakaran. Kondisi jalan lingkungan di FIK UM telah tersedia dengan lebar 5,8 meter dan diberi pengerasan paving block. Sub komponen jarak antar bangunan pada bangunan gedung FIK UM telah memenuhi persyaratan dan mendapat nilai 5,75\% dan termasuk kategori baik, serta dapat memberikan perlindungan terhadap bahaya kebakaran. Bangunan terdekat dari bangunan gedung FIK UM adalah masjid Al-Hikmah UM dengan jarak mencapai 15 meter. Jarak antar bangunan yang cukup dapat mengurangi risiko bahaya kebakaran dan menghambat proses penyebaran api kebakaran.

Sub komponen hidran halaman pada bangunan gedung FIK UM termasuk kategori "K" (Kurang) dengan nilai 3,75\%, karena tidak ada peralatan dalam kotak hidran yang berwarna merah dengan tulisan "HYDRANT" berwarna putih. dan juga kotak hidran halaman tidak dikunci serta berisi batu. Hidran halaman pada bangunan gedung FIK UM dapat dikatakan tidak siap digunakan karena peralatan yang tidak lengkap atau kosong serta tidak diketahui berapa supply airnya. Kelengkapan hidran halaman yang kurang dapat menghambat proses pemadaman kebakaran dan juga dapat menambah kerugian apabila terjadi kebakaran, karena tidak ada pemadaman api tahap awal sehingga api dapat membesar dengan cepat. Penilaian komponen kelengkapan tapak pada bangunan gedung FIK UM memperoleh nilai hampir sempurna, meskipun ada satu sub komponen yang kurang, yaitu sub komponen hidran halaman. Komponen kelengkapan tapak yang hampir mendapatkan hasil yang andal dapat mencegah dan meminimalisir bahaya kebakaran seperti penelitian yang dilakukan di Ayola First Point oleh (Wulandari \& Trikomara, 2018) yang memperoleh nilai 23,28\%. Penelitian terkait komponen kelengkapan tapak juga dilakukan oleh (Oktareza \& Iriana, 2018) di Hotel Pesonna Pekanbaru yang memperoleh nilai $21,35 \%$ untuk komponen kelengkapan tapak dan di Gedung Polda Jateng oleh (Gultom et al., 2018) yang memperoleh nilai 23,85\%.

Tabel 3. Penilaian Komponen Kelengkapan Tapak

\begin{tabular}{ccccccc}
\hline No. & KSKB / SUB KSKB & Hasil Penilaian & Stan. Penilaian & Bobot & Nilai Kondisi & Jumlah Nilai \\
\hline $\mathbf{1}$ & \multicolumn{1}{c}{$\mathbf{2}$} & $\mathbf{3}$ & $\mathbf{4}$ & $\mathbf{5}$ & $\mathbf{6}$ & $\mathbf{7}$ \\
\hline Kelengkapan Tapak & & & $\mathbf{2 5}$ & & \\
\hline 1. & Sumber air & B & 100 & 27 & 27 & 6,75 \\
2. & Jalan Lingkungan & B & 90 & 25 & 22,5 & 5,62 \\
3. & Jarak Antar & B & 100 & 23 & 23 & 5,75 \\
& Bangunan & K & 60 & 25 & 15 & 3,75 \\
4. & Hidran Halaman & & & & Jumlah & 21,87 \\
\hline
\end{tabular}

\subsection{Sarana Penyelamatan Jiwa}

Bangunan gedung FIK UM memiliki sarana penyelamatan yang termasuk kategori "B" (Baik) dengan nilai 23,17\% dari 25\%. Sarana penyelamatan yang baik dapat melakukan proses evakuasi terhadap penghuni maupun pengunjung bangunan gedung saat terjadi keadaan 
darurat, karena langkah utama pada saat terjadinya kebakaran adalah menyelamatkan penghuni atau manusia yang berada di lokasi kejadian (Pratama, 2016). Sub komponen jalan keluar yang tersedia pada bangunan gedung FIK UM sudah memenuhi persyaratan Pd-T-112005-C dengan nilai 8,55\%. Bangunan gedung FIK UM memiliki tiga jalan keluar, dua diantaranya merupakan tangga darurat dan terlindungi oleh pintu tahan api, serta satu tangga yang digunakan untuk aktivitas setiap hari. Tanda eksit juga terpasang pada setiap jalan keluar, serta tidak terdapat hambatan meskipun dua diantaranya sedikit berdebu karena tidak sering digunakan. Eksit pada bangunan gedung FIK UM juga tidak terhalang serta eksit menuju ke ruang terbuka. Safety sign pada bangunan gedung FIK UM hanya terdapat tanda "exit" yang berada pada langit-langit dan mengarah ke tangga darurat atau tangga yang digunakan untuk aktivitas setiap hari, tidak ada safety sign yang lain. Pemenuhan kriteria sub komponen konstruksi jalan keluar termasuk kategori "B" (Baik) dengan nilai 7,87\%. Lebar konstruksi jalan keluar yang terdapat pada bangunan gedung FIK UM adalah empat meter dan sudah memenuhi kriteria penilaian dimana lebar konstruksi jalan keluar diharuskan lebar minimal dua meter (Hidayat et al., 2017). Bangunan gedung FIK UM memiliki tinggi 34,25 meter dan dianggap tidak memerlukan landasan helikopter. Syarat diwajibkannya memiliki landasan helikopter yaitu bangunan gedung memiliki tinggi minimal 60 meter (Mareta \& Hidayat, 2020) sehingga tidak dilakukan penilaian. Penilaian komponen sarana penyelamatan jiwa bangunan gedung FIK UM yang termasuk kategori baik, sejalan dengan penelitian yang dilakukan di RSUD Kabupaten Bekasi dengan memperoleh nilai 23,25\% dan termasuk kategori baik (Sari \& Sukwika, 2020). Penelitian yang dilakukan oleh (Zulfiar \& Gunawan, 2018) tidak melakukan penilaian terhadap sub komponen landasan helikopter dikarenakan bangunan Hotel UNY tidak memiliki landasan helikopter dan memperoleh nilai 25\% untuk komponen sarana penyelamatan. Penelitian yang dilakukan (Wulandari \& Trikomara, 2018) juga tidak melakukan penilaian terhadap sub komponen landasan kebakaran pada Ayola First Point Hotel Pekanbaru dan memperoleh nilai $23,7 \%$. Pemenuhan kelengkapan sarana penyelamatan jiwa adalah aspek pokok yang harus dipenuhi untuk meminimalisir potensi risiko suatu kebakaran (Aldiansyah et al., 2020).

Tabel 4. Penilaian Komponen Sarana Penyelamatan

\begin{tabular}{llccccc}
\hline No. & KSKB / SUB KSKB & Hasil Penilaian & Stan. Penilaian & Bobot & Nilai Kondisi & Jumlah Nilai \\
\hline \multicolumn{1}{c}{$\mathbf{2}$} & $\mathbf{2}$ & $\mathbf{3}$ & $\mathbf{4}$ & $\mathbf{5}$ & $\mathbf{6}$ & $\mathbf{7}$ \\
\hline Sarana Penyelamatan & & & 25 & & \\
1. & Jalan Keluar & B & 90 & 38 & 34,2 & 12,05 \\
2. & Konstruksi Jalan Keluar & B & 90 & 35 & 31,5 & 11,12 \\
3. & Landasan Helikopter & - & - & 27 & - & - \\
\hline
\end{tabular}

\subsection{Sistem Proteksi Aktif Gedung FIK UM Terhadap Bahaya Kebakaran}

Sistem proteksi aktif merupakan alat yang dapat bekerja secara otomatis maupun manual yang digunakan untuk proses pemadaman api dan dapat digunakan baik oleh petugas pemadam kebakaran maupun penghuni atau pengunjung bangunan (Ratnayanti et al., 2019). Sistem proteksi aktif yang tersedia di bangunan gedung FIK UM secara keseluruhan termasuk kategori baik dengan nilai 21,34\% dari 24\%, meskipun ada beberapa sub komponen yang termasuk kategori "C" (Cukup) dan "K" (Kurang). Terdapat 13 sub komponen yang dilakukan penilaian dalam komponen sistem proteksi aktif. Sub komponen deteksi dan alarm, cahaya 
darurat dan ruang pengendali operasi termasuk kategori cukup, sedangkan sub komponen lift kebakaran termasuk kategori kurang. Sub komponen deteksi dan alarm termasuk kategori cukup dengan hasil penilaian 1,53\% dari nilai maksimal 1,92\%. Deteksi dan alarm telah terpasang di bangunan gedung FIK UM, tetapi belum pernah dilakukan uji coba pada alat tersebut. Sub komponen siamese connection yang tersedia di bangunan gedung FIK UM termasuk kategori baik dengan nilai 1,92\% dari 1,92\%. Siamese connection berjumlah satu dan terletak pada depan bangunan gedung dan dapat terlihat oleh petugas pemadam kebakaran. Sub komponen alat pemadam api ringan atau APAR yang tersedia pada bangunan gedung FIK UM termasuk kategori baik dengan nilai $1,72 \%$ dari $1,92 \%$. Pemadam api ringan pada bangunan gedung FIK UM menggunakan APAR dengan jenis dry chemical yang terletak pada setiap lantai. Jarak antar APAR adalah 5 - 15 meter, serta jarak APAR dengan lantai adalah 1,2 meter, tetapi belum terdapat label pemeliharaan di setiap APAR. Penempatan dan penentuan kebutuhan APAR dilakukan dengan melakukan perhitungan berdasarkan luas bangunan atau lantai yang harus dilindungi, serta sesuai dengan kelas kebakaran dan jarak penempatannya adalah 15 meter (Pradipta, 2017).

Sub komponen hidran gedung pada bangunan gedung FIK UM termasuk dalam kategori baik dengan nilai 1,92\% dari 1,92\%. Kelengkapan fasilitas pada sub komponen hidran gedung termasuk lengkap karena tersedia slang dengan panjang 30 meter dan diameter $39 \mathrm{~mm}$. Lokasi hidran gedung pada bangunan gedung FIK UM terletak pada sisi barat dan timur bangunan dengan lokasi yang mudah dijangkau. Hidran gedung mudah dikenali dengan kotak berwarna merah serta terdapat tulisan "HYDRANT". Sub komponen sprinkler pada bangunan gedung FIK UM termasuk kategori baik dengan nilai 1,72\% dari 1,92\%. Jarak antar sprinkler pada bangunan gedung FIK UM yaitu 4,6 meter dengan jumlah sprinkler di setiap lantainya adalah sama. Sub komponen sistem pemadam luapan yang ada di bangunan gedung FIK UM termasuk kategori baik dengan nilai 1,68\% dari 1,68\%. Sub komponen pengendali asap dan sub komponen detektor asap pada bangunan gedung FIK UM juga termasuk kategori baik dengan nilai sub komponen pengendalian asap 1,92\% dari 1,92\%. Sub komponen deteksi asap dan juga sub komponen pembuangan asap pada bangunan gedung FIK UM termasuk kategori baik dengan nilai sub komponen deteksi asap 1,72\% dari 1,92\% serta sub komponen pembuangan asap 1,42\% dari 1,68\%. Jarak antar detektor adalah tidak lebih dari 10 meter dan tersedia pada setiap lantai termasuk laboratorium gizi dan juga dapur serta dalam kondisi yang layak. Pembuangan asap pada bangunan gedung FIK UM menggunakan kipas yang tersedia pada setiap ruangan, tetapi tidak diketahui lokasi reservoir asap pada bangunan gedung FIK UM. Sub komponen lift kebakaran pada bangunan gedung FIK UM termasuk kategori kurang dengan nilai 1\% dari 1,68\% dikarenakan bangunan gedung FIK UM tidak memiliki lift kebakaran.

Sub komponen pencahayaan darurat pada bangunan gedung FIK UM termasuk kategori cukup dengan nilai 1,53\% dari 1,92\%. Bangunan gedung FIK UM belum memiliki pencahayaan darurat, tetapi pada tangga darurat tersedia pencahayaan dari lampu pada umumnya. Sub komponen listrik darurat pada bangunan gedung FIK UM termasuk kategori baik dengan nilai 1,92\% dari 1,92\%. Listrik darurat berasal dari generator yang terletak di sebelah barat bangunan gedung dan instalasi kabel menggunakan kabel yang sudah sesuai dengan SNI. Sub komponen ruang pengendali operasi pada bangunan gedung FIK UM termasuk kategori cukup dengan nilai $1,34 \%$ dari $1,68 \%$. Perangkat yang tersedia di ruang pengendali operasi merupakan peralatan sederhana yaitu monitor untuk memantau CCTV. Penilaian komponen sistem proteksi aktif pada bangunan gedung FIK UM sejalan dengan penelitian yang dilakukan (Zulfiar \& Gunawan, 2018) yang membahas tentang evaluasi sistem proteksi kebakaran pada 
bangunan hotel UNY 5 lantai di Yogyakarta, dimana hasil yang diperoleh untuk penilaian sistem proteksi aktifnya adalah 20,04\% dari 24\%. Penelitian di Gedung Menara BRI Pekanbaru yang dilakukan oleh (Amtria et al., 2020) memperoleh nilai 22,77\% untuk sistem proteksi aktif. Penelitian yang dilakukan (Wulandari \& Trikomara, 2018) memperoleh nilai 19,40\% dengan 12 sub komponen yang dilakukan penilaian pada bangunan Ayola First Point Hotel Pekanbaru.

Tabel 5. Penilaian Komponen Sistem Proteksi Aktif

\begin{tabular}{llccccc}
\hline No. & \multicolumn{1}{c}{ KSKB / SUB KSKB } & $\begin{array}{c}\text { Hasil } \\
\text { Penilaian }\end{array}$ & $\begin{array}{c}\text { Stan. } \\
\text { Penilaian }\end{array}$ & Bobot & $\begin{array}{c}\text { Nilai } \\
\text { Kondisi }\end{array}$ & $\begin{array}{c}\text { Jumlah } \\
\text { Nilai }\end{array}$ \\
\hline \multicolumn{1}{c}{$\mathbf{2}$} & $\mathbf{3}$ & $\mathbf{4}$ & $\mathbf{5}$ & $\mathbf{6}$ & $\mathbf{7}$ \\
\hline Proteksi Aktif & & & $\mathbf{2 4}$ & & \\
\hline 1. & Deteksi dan Alarm & $\mathrm{C}$ & 80 & 8 & 6,4 & 1,53 \\
2. & Siamese connection & $\mathrm{B}$ & 100 & 8 & 8 & 1,92 \\
3. & Pemadam Api Ringan & $\mathrm{B}$ & 90 & 8 & 7,2 & 1,72 \\
4. & Hidran Gedung & $\mathrm{B}$ & 100 & 8 & 8 & 1,92 \\
5. & Sprinkler & $\mathrm{B}$ & 90 & 8 & 7,2 & 1,72 \\
6. & Sistem Pemadam luapan & $\mathrm{B}$ & 100 & 7 & 7 & 1,68 \\
7. & Pengendali Asap & $\mathrm{B}$ & 100 & 8 & 8 & 1,92 \\
8. & Deteksi Asap & $\mathrm{B}$ & 90 & 8 & 7,2 & 1,72 \\
9. & Pembuangan Asap & $\mathrm{B}$ & 85 & 7 & 5,9 & 1,42 \\
10. & Lift Kebakaran & $\mathrm{K}$ & 60 & 7 & 4,2 & 1 \\
11. & Cahaya Darurat & $\mathrm{C}$ & 80 & 8 & 6,4 & 1,53 \\
12. & Listrik Darurat & $\mathrm{B}$ & 100 & 8 & 8 & 1,92 \\
13. & Ruang Pengendali & $\mathrm{C}$ & 80 & 7 & 5,6 & 1,34 \\
& Operasi & & & & Jumlah & 21,34 \\
\hline
\end{tabular}

\subsection{Sistem Proteksi Pasif Gedung FIK UM Terhadap Bahaya Kebakaran}

Sistem proteksi pasif pada bangunan gedung FIK UM secara keseluruhan termasuk kategori baik berdasarkan penilaian tiga sub komponen dengan nilai $23,38 \%$ dari $26 \%$. Syarat kelayakan penggunaan harus dimiliki pada sistem proteksi pasif guna sebagai cara untuk menyelamatkan diri dari potensi bahaya kebakaran (Mufida \& Martiana, 2019). Sub komponen ketahanan api struktur mendapatkan nilai $8,42 \%$ dan termasuk kedalam kategori baik. Bangunan gedung FIK UM termasuk kedalam tipe C dikarenakan memiliki luas bangunan 2400 $\mathrm{m}^{2}$ dan memiliki fungsi sebagai bangunan sosial budaya. Sub komponen kompartemenisasi ruang pada bangunan gedung FIK UM termasuk kategori baik dengan nilai 7,48\%. Kompartemenisasi ruang adalah telah tersedia sprinkler, jalan masuk kendaraan pemadam kebakaran, dan sistem pembuangan asap otomatis. Lebar jalan pada bagian depan bangunan gedung dapat dilalui mobil pemadam kebakaran tetapi tidak untuk bagian samping dan belakang bangunan gedung. Sub komponen perlindungan bukaan termasuk dalam kategori baik dengan nilai $7,48 \%$.

Hasil penelitian yang telah dilaksanakan oleh peneliti selaras dengan penelitian yang dilakukan oleh (Mareta \& Hidayat, 2020) yang berjudul "Evaluasi Penerapan Sistem Keselamatan Kebakaran Pada Gedung-Gedung Umum di Kota Payakumbuh" dengan nilai untuk sistem proteksi pasif yaitu di gedung rumah sakit (A1) bernilai 22,6\% dan untuk gedung kantor memperoleh nilai 21,01\%. Penelitian yang dilakukan oleh (Sari \& Sukwika, 2020) memperoleh nilai 24,34\% untuk sistem proteksi pasif pada RSUD Kabupaten Bekasi. Penilaian sistem proteksi pasif juga dilakukan oleh (Oktareza \& Iriana, 2018) di Hotel Pesonna Pekanbaru yang 
memperoleh nilai sempurna yaitu $26 \%$. Nilai bobot KSKB secara total adalah $26 \%$ dan nilai bobot KSKB bangunan gedung FIK UM adalah 23,38\% yang dapat dikatakan hampir sempurna. Hal ini menunjukkan bahwa nilai keandalan bangunan dalam kategori baik dan sesuai dengan peraturan yang berlaku.

\subsection{Pencegahan dan Pengendalian Bahaya Kebakaran dengan Hierarchy Of Control}

Tabel 6. Penilaian Komponen Sistem Proteksi Pasif

\begin{tabular}{llccccc}
\hline No. & \multicolumn{1}{c}{ KSKB / SUB KSKB } & $\begin{array}{c}\text { Hasil } \\
\text { Penilaian }\end{array}$ & $\begin{array}{c}\text { Stan. } \\
\text { Penilaian }\end{array}$ & Bobot & $\begin{array}{c}\text { Nilai } \\
\text { Kondisi }\end{array}$ & $\begin{array}{c}\text { Jumlah } \\
\text { Nilai }\end{array}$ \\
\hline \multicolumn{1}{c}{$\mathbf{1}$} & $\mathbf{2}$ & $\mathbf{3}$ & $\mathbf{4}$ & $\mathbf{5}$ & $\mathbf{6}$ & $\mathbf{7}$ \\
\hline Proteksi Pasif & & & $\mathbf{2 6}$ & & \\
\hline $1 . \quad \begin{array}{l}\text { Ketah. Api Strk. } \\
\text { Bangunan }\end{array}$ & $\mathrm{B}$ & 90 & 36 & 32,4 & 8,42 \\
2. & $\begin{array}{l}\text { Kompartemenisasi } \\
\text { Ruang }\end{array}$ & B & 90 & 32 & 28,8 & 7,48 \\
3. & Perlindungan Bukaan & B & 90 & 32 & $\begin{array}{c}28,8 \\
\text { Jumlah }\end{array}$ & $\begin{array}{c}7.48 \\
23,38\end{array}$ \\
\hline
\end{tabular}

Rekomendasi yang disarankan oleh Puslitbang Kementerian Pekerjaan Umum berdasarkan hasil penilaian $89,76 \%$ adalah pemeriksaan berkala, perawatan/pemeliharaan berkala, perawatan dan perbaikan berkala yang terdapat pada pokok rekomendasi dengan tujuan untuk meningkatkan sub komponen dengan kondisi kurang atau cukup menjadi kondisi baik. Rekomendasi tersebut diberikan berdasarkan pedoman pemeriksaan keselamatan kebakaran bangunan gedung (Pd-T-11-2005-C). Hasil penelitian yang dilakukan menggunakan pedoman observasi John Stephenson Associates Fire Safety/Training Consultants didapatkan hasil bahwa bangunan gedung FIK UM termasuk level risiko sedang dan level risiko rendah. Tingkat risiko yang termasuk dalam kategori level risiko sedang sangat disarankan untuk melakukan tindakan yang harus diselesaikan dalam waktu enam bulan kedepan untuk dilakukannya perbaikan fasilitas atau pemenuhan persyaratan fasilitas. Tingkat risiko yang termasuk dalam kategori rendah diharapkan melakukan tindakan yang harus diselesaikan dalam waktu 12 bulan kedepan dalam pemenuhan persyaratan maupun perbaikan fasilitas.

Pengendalian dan pencegahan bahaya kebakaran dapat dilakukan dengan menggunakan hierarchy of control dikarenakan dapat meminimalisir atau mengurangi tingkat risiko yang ada sampai ke tingkat risiko yang terendah dengan cara eliminasi, subtitusi, rekayasa teknik, pengaturan administratif dan juga APD (Soputan et al., 2014). Upaya pengendalian dan pencegahan risiko yang dapat dilakukan di bangunan gedung FIK UM berdasarkan hierarchy of control adalah rekayasa teknik dan pengaturan administratif. Prioritas tindakan di bangunan gedung FIK UM juga harus diselesaikan dalam waktu 6-12 bulan kedepan. Pengendalian tersebut bertujuan untuk memberikan keamanan dan keselamatan pengguna bangunan gedung FIK UM.

Pengendalian rekayasa teknik pada bangunan gedung FIK UM yaitu menyediakan smoking area; Melengkapi fasilitas smoking area; Memberikan pelindung terhadap jalur kabel; Memasang penangkal petir atau memberi penanda pada penangkal petir; Menentukan lokasi yang digunakan sebagai area titik kumpul; Menentukan lokasi alternatif yang digunakan 
sebagai titik kumpul. Pengendalian tersebut disarankan untuk upaya pencegahan apabila terjadi keadaan darurat dan dapat meminimalisir kerugian yang ditimbulkan.

Pengendalian pengaturan administratif pada bangunan gedung FIK UM dapat dilakukan dengan memastikan penilaian risiko sudah dilakukan di bangunan gedung FIK UM serta membuat arsip dokumen penilaian risiko; Melakukan pemantauan, pengujian, dan pemeriksaan secara berkala terhadap fasilitas yang ada di bangunan gedung FIK UM; Membuat prosedur peninjauan penilaian risiko secara berkala apabila ada perubahan pada bangunan gedung; Membuat catatan atau arsip terkait pengujian rutin terhadap instalasi dan juga fasilitas; Melakukan simulasi atau demonstrasi terkait risiko bahaya yang ada di bangunan gedung FIK UM; Melakukan simulasi terkait upaya pencegahan kebakaran dasar; Membuat pemberitahuan safety briefing terkait prosedur evakuasi darurat; Melakukan simulasi evakuasi darurat; Membuat prosedur evakuasi darurat secara tertulis; Membuat rencana evakuasi darurat pribadi; Pemilihan atau penunjukkan terhadap staf yang dapat memenuhi tugasnya apabila terjadi kebakaran; Membuat jadwal tentang pelatihan evakuasi darurat; Melakukan penilaian terkait risiko lingkungan apabila terjadi kebakaran; Membuat rambu K3 seperti rambu titik kumpul, smoking area, rute pelarian, pictogram, poster terkait evakuasi darurat.

\section{Simpulan}

Berdasarkan hasil penelitian yang dilakukan oleh peneliti dapat disimpulkan bahwa kelengkapan fasilitas safety building pada bangunan gedung FIK UM termasuk lengkap berdasarkan penilaian keandalan bangunan, dikarenakan hampir semua sub komponen terpenuhi dan termasuk dalam kategori cukup hingga baik, meskipun ada dua sub komponen yang termasuk kategori kurang yaitu sub komponen lift kebakaran dan sub komponen hidran halaman. Kelayakan fungsi fasilitas safety building pada gedung FIK UM termasuk dalam kategori layak berdasarkan penilaian keandalan bangunan dikarenakan hampir semua sub komponen memenuhi persyaratan saat dilakukan penilaian. Hasil penilaian sub komponen kelengkapan tapak termasuk baik, sub komponen sarana penyelamatan termasuk cukup, sub komponen sistem proteksi aktif termasuk baik, sub komponen sistem proteksi pasif termasuk baik. Upaya optimalisasi bangunan gedung FIK UM yang diperlukan yaitu melakukan upaya pengendalian rekayasa teknik dan pengaturan administratif.

\section{Daftar Rujukan}

Aldiansyah, M., Akbar, K. A., \& Hartanti, R. I. (2020). Analisis Sarana Penyelamatan Jiwa Sebagai Upaya Tanggap Darurat Kebakaran ( Studi Di Unit Produksi Plywood Pt. Kutai Timber Indonesia Probolinggo ) Analysis on Means of Escape As Fire Emergency Response ( Study in Plywood Production Unit of Pt . Kutai Ti. Journal of Industrial Hygiene and Occupational Health, 5(1).

Amtria, R., Taufik, H., \& Trikomara, R. (2020). Analisis Keandalan Sistem Proteksi Kebakaran Pada Gedung Menara BRI Pekanbaru. Jurnal Sainstek STT Pekanbaru, 08(1), 1-6.

BPBD. (2020). [Update] Sepanjang 2019, 119 Bangunan Rusak Akibat Bencana. BPBD Kota Malang. https://bpbd.malangkota.go.id/2020/01/01/sepanjang-2019-114-bangunan-rusak-akibat-bencana/

Chen, Y., Wang, P., \& Liu, X. (2019). Numerical Study on Suppression of Post-flashover Compartment Fire by Using Water Mist. 2019 9th International Conference on Fire Science and Fire Protection Engineering, ICFSFPE 2019. https://doi.org/10.1109/ICFSFPE48751.2019.9055792

Data Informasi Bencana Indonesia. (2020). Data Informasi Bencana Indonesia Tahun 2005-2019. http://bnpb.cloud/dibi/tabel3b

Dipiarsa, P. A. A., Yunus, M., \& Andiana, O. (2020). Analisis Gerak Pada Shooting Menggunakan Punggung Kaki Dalam Olahraga Sepak Bola (Studi Kasus Pada Sekolah Sepakbola Putra Arema U-15). Journal of Sport Science and Health, 2(2), 137-144. 
Dodi. (2020). Laboratorium di UPR Terbakar, Kerugian Ditaksir Ratusan Juta | Radar Sampit. Radar Sampit. https://sampit.prokal.co/read/news/27668-laboratorium-di-upr-terbakar-kerugian-ditaksirratusan-juta.html

Gultom, T. H., Kurniawan, B., \& Lestantyo, D. (2018). Analisis Keandalan Sistem Keselamatan Bangunan Sebagai Proteksi Kebakaran Pada Gedung Polda Jawa Tengah. Jurnal Kesehatan Masyarakat (e-Journal), 6(5), 643-647.

Hambyah, R. F. (2016). Evaluasi Pemasangan APAR Dalam Sistem Tanggap Darurat Kebakaran Di Gedung Bedah RSUD Dr. Soetomo Surabaya. The Indonesian Journal of Occupational Safety and Health, 5(1), 4150.

Harianja, E. S., Toruan, M. L., \& Hasibuan, A. S. (2020). Analisis Penerapan Sistem Proteksi Kebakaran Aktif Dalam Upaya Pencegahan dan Penanggulangan Bahaya Kebakaran Di PTPN IV Unit PKS Pabatu, Serdang Bedagai. Journal of Healthcare Technology and Medicine, 6(2), 1020-1030. https://doi.org/10.33143/jhtm.v6i2.1088

Hidayat, D. A., Suroto, \& Kurniawan, B. (2017). Evaluasi Keandalan Sistem Proteksi Kebakaran Ditinjau Dari Sarana Penyelamatan Dan Sistem Proteksi Pasif Kebakaran Di Gedung Lawang Sewu Semarang. Jurnal Kesehatan Masyarakat (e-Journal), 5(5), 134-146.

Kowara, R. A., \& Martiana, T. (2017). Analisis Sistem Proteksi Kebakaran sebagai Upaya Pencegahan dan Penanggulangan Kebakaran (Studi di PT. PJB UP Brantas Malang). Jurnal Manajemen Kesehatan Yayasan Dr. Soetomo, 3(1), 70-85.

Lestari, W. T., \& Winarno, M. E. (2020). Efektifitas Waktu Pelaksanaan Pembelajaran Pendidikan Jasmani, Olahraga dan Kesehatan di UPT Sekolah Dasar. Sport Science and Health, 2(9), 464-470. http://journal.um.ac.id/index.php/jptpp/article/view/13303

Mareta, Y., \& Hidayat, B. (2020). Evaluasi Penerapan Sistem Keselamatan Kebakaran Pada Gedung-Gedung Umum Di Kota Payakumbuh. Jurnal Rekayasa Sipil (JRS-Unand), 16(1), 65. https://doi.org/10.25077/jrs.16.1.65-76.2020

Michico, N. R. (2019). 19 Mahasiswa Tewas akibat Kebakaran di Gedung Universitas India. Inews. https://www.inews.id/news/internasional/19-mahasiswa-tewas-akibat-kebakaran-di-gedunguniversitas-india

Mufida, M. R., \& Martiana, T. (2019). Sistem Tanggap Darurat Kebakaran Di Gedung Administrasi Perusahaan Listrik. The Indonesian Journal of Occupational Safety and Health, 8(1), 47-56. https://doi.org/10.20473/ijosh.v8i1.2019.47

Mustika, S. W., Wardani, R. S., \& Prasetio, D. B. (2018). Penilaian Risiko Kebakaran Gedung Bertingkat. Jurnal Kesehatan Masyarakat Indonesia, 13(1), 18-25.

Oktareza, E., \& Iriana, R. T. K. (2018). Keandalan Sistem Proteksi Kebakaran Pada Gedung (Studi Kasus : Hotel Pesona Pekanbaru). Jom FTEKNIK, 5(2), 1-8. https://doi.org/10.30853/filnauki.2018-11-2.39

Pradipta, Y. (2017). Identifikasi Kebutuhan Alat Pemadam Api Ringan Di Rsp Universitas Brawijaya Malang. The Indonesian Journal of Occupational Safety and Health, 5(1), 11-20. https://doi.org/10.20473/ijosh.v5i1.2016.11-20

Pratama, A. (2016). Perancangan Sarana Penyelamat Diri dan Kebutuhan Apar pada Darurat Kebakaran Di Kantor Kesehatan Pelabuhan Kelas II Balikpapan. The Indonesian Journal of Occupational Safety and Health, 5(1), 21-30.

Raharjo, D. B. (2020). Terdengar Suara Ledakan di Kampus Undiksha Singaraja, Ruangan Lab Terbakar. Suara. https://www.suara.com/news/2020/01/15/105655/terdengar-suara-ledakan-di-kampus-undikshasingaraja-ruangan-lab-terbakar

Ratnayanti, K. R., Hajati, N. L., \& Utama, M. I. R. (2019). Evaluasi Sistem Proteksi Aktif Dan Pasif Sebagai Upaya Penanggulangan Bahaya Kebakaran Pada Gedung X Mall. Jurnal Rekayasa Hijau, 3(1), 1-16.

Reinaldo, I. (2018). Sengketa Izin Mendirikan Bangunan (IMB) Pada Bangunan Gedung Dalam Peradilan Tata Usaha Negara. Lex Administratum, VI(3), 142-152.

Riskiyanto, R., Harani, A. R., \& Pertiwi, A. C. (2018). Kajian Sirkulasi Vertikal dan Horizontal bagi Atlet Pengguna Wheelchair di Gedung Olahraga Manahan, Surakarta. Arsir, 2(1), 28. https://doi.org/10.32502/arsir.v2i1.1236 
Sari, M. L., \& Sukwika, T. (2020). Sistem Proteksi Aktif Dan Sarana Penyelamatan Jiwa Dari Kebakaran Di RSUD Kabupaten Bekasi. Jurnal Ilmu Kesehatan Bhakti Husada: Health Sciences Journal, 11(2), 190-203. https://doi.org/10.34305/jikbh.v11i2.184

Setyawati, D., \& Suhardi. (2018). Keselamatan Konstruksi Bangunan Gedung Fasilitas Layanan Umum Dengan Readibess Fasilitas Tanggap Darurat. In Jurnal Teknologi Sipil.

Soputan, G., Sompie, B., \& Mandagi, R. (2014). Manajemen Risiko Kesehatan Dan Keselamatan Kerja (K3) (Study Kasus Pada Pembangunan Gedung Sma Eben Haezar). Jurnal Ilmiah Media Engineering, 4(4), 99095.

Sufianto, H., Nugroho, A. M., \& Aditama, M. S. (2015). Framework Tanggap Bencana Kebakaran Gedung Kampus. Jurnal Arsitek Dan Perkotaan "KORIDOR," 09(01), 1-8.

Wulandari, B., \& Trikomara, R. (2018). Analisis Keandalan Sistem Proteksi Kebakaran Pada Bangunan Ayola First Point Hotel Pekanbaru. Jom FTEKNIK, 5(1), 1-9.

Zulfiar, M. H., \& Gunawan, A. (2018). Evaluasi Sistem Proteksi Kebakaran pada Bangunan Hotel UNY 5 Lantai. Semesta Teknika, 21(1), 65-71. https://doi.org/10.18196/st.211212 